\title{
PENGARUH INTENSITAS PENGGUNAAN GAME GADGET TERHADAP MINAT BELAJAR SISWA
}

\author{
Al Nizar ${ }^{1}$ dan Siti Hajaroh ${ }^{2}$ \\ ${ }^{1}$ Universitas Islam Negeri Mataram \\ Email: ${ }^{1}$ alnizar@uinmataram.ac.id ${ }^{2}$ sitihajaroh@uinmataram.ac.id
}

\begin{abstract}
Abstrak: Penelitian ini bertujuan untuk mengetahui pengaruh intensitas penggunaan game gadget terhadap minat belajar siswa. Penelitian ini merupakan penelitian kuantitatif dengan pendekatan ex-post facto. Populasi dalam penelitian ini adalah siswa kelas V MI NW Gelogor sebanyak 26 siswa dengan pengambilan sampel menggunakan sampel jenuh sehingga jumlah sampel sebanyak 26 siswa. Teknik pengumpulan data menggunakan angket dan dokumentasi. Teknik analisis data dilakukan dengan analisis deskriptif dan analisis regresi sederhana setelah uji prasyarat dilakukan. Hasil penelitian menunjukkan bahwa terdapat pengaruh intensitas penggunaan game gadget terhadap minat belajar siswa kelas V MI NW Gelogor tahun pelajaran 2017/2018 sebesar 40\% dan 60\% dipengaruhi variabel lain yang tidak diteliti. Terdapat pengaruh negatif signifikan kuat yang ditunjukan dengan nilai korelasi (r) sebesar -0,63081, terbukti signifikan dengan nilai t hitung $=3,982$ dibandingkan dengan $\mathrm{t}$ tabel $=2,064$ sehingga hipotesis yang diajukan dapat diterima. Dari hasil analisis regresi liniear sederhananya diperoleh persamaan regresi $Y=63,94-0,46 \mathrm{X}$. dimana konstanta sebesar 63,94: artinya jika intensitas penggunaan game gadget $(\mathrm{X})$ nilainya 0 , maka minat belajar siswa (Y) nilainya yaitu sebesar 63,94. Koefisien regresi variabel minat belajar siswa sebesar -0,46: artinya jika intensitas penggunaan game gadget mengalami kenaikan 1, maka minat belajar siswa $(\mathrm{Y})$ akan mengalami penurunan sebesar -0,46. Ini berarti semakin naik intensitas penggunaan game gadget maka semakin menurun minat belajar siswa dan sebaliknya.
\end{abstract}

Kata Kunci: Intensitas, Penggunaan Game Gadget, Minat Belajar Siswa

\section{PENDAHULUAN}

Kemajuan teknologi informasi dan komunikasi sering menjadi penghalang tumbuh dan berkembangnya minat belajar anak. Media digital dan elektronik telah berhasil menarik perhatian kebanyakan anak Indonesia yang secara langsung dan tidak langsung memicu aktivitas keseharian mereka lebih terkonsentrasi pada pemanfaatan media tersebut. Bahkan media telah mengambil alih peran orang tua dalam mengembangkan kepribadian anak. Hal ini sejalan dengan pandangan Yaumi, yang mengatakan bahwa anak yang hidup di perkotaan dan pedesaan memiliki kebiasaan menonton televisi dan bermain video game, playstation, game gadget dan internet yang rasionya 19 kali berbanding satu kali berbicara dengan orangtua. ${ }^{1}$

${ }^{1}$ Muhammmad Yaumi, Pendidikan Karakter Landasan, Pilar, dan Implementasi, (Jakarta: Kencana, 2014), hlm. 155. 
Anak-anak biasanya mendapatkan gadget dari kedua orang tuanya untuk sebagai hiburan. Awalnya penggunaan pertama hanya diisi dengan fitur audio seperti musik supaya anak tidak jenuh dan menjadi media hiburan untuk anak-anaknya. Namun lama kelamaan anak-anak biasanya bosan dengan konten atau fitur yang ada. Sehingga anak-anak luput dari pengawasan orangtua. Dan anak-anak akan memanfaatkan gadget untuk kepentingan bermain game yang menyenangkan daripada komunikasi. Sehingga anak-anak menjadi terlena dengan gadget dan tidak peduli lagi dengan lingkungan dan belajarnya.

Game merupakan aktivitas yang dilakukan untuk hiburan atau menyenangkan yang memiliki aturan sehingga ada yang menang dan kalah. Anak yang mengalami ketergantungan pada aktivitas games, akan mempengaruhi minat belajar sehingga mengurangi waktu belajar dan waktu untuk bersosialisasi dengan teman sebaya mereka, ini berlangsung terus menerus dalam waktu yang lama.

Berdasarkan temuan hasil observasi di kelas V MI NW Gelogor terdapat beberapa siswa di sekolah mengalami perubahan sikap minat belajarnya menurun, ingin cepat pulang, tidak fokus ketika proses belajar mengajar. Hal ini tampak ketika proses belajar beberapa siswa dalam proses pembelajarannya sibuk sendiri, bercerita dengan temannya, tidak semangat belajar, melamun, ingin cepat keluar kelas sebelum jam istirahat, dan ingin cepat pulang. ${ }^{2}$ Ini disebabkan karena anak terpengaruh oleh game gadget yang mereka mainkan, sehingga pada saat belajar di sekolah anak terbayang-bayang dengan permainan game gadgetnya.

Hasil wawancara juga memberikan informasi senada, beberapa siswa menyatakan bahwa mereka ingin cepat pulang sekolah karena ingin bermain game. Bahkan pengakuan dari beberapa siswa, sepulang sekolah mereka lebih suka bermain game daripada istirahat. Sebelum atau sesudah bangun tidur mereka memegang gadget untuk bermain game. Di saat waktu libur mereka meluangkan waktu liburnya dengan bermain game, hal ini tampak dari pengakuan beberapa siswa pada waktu libur sekolah beberapa siswa kumpul bersama teman-temannya hanya untuk bermain game bersama-sama, dari beberapa siswa mengatakan pada saat orang tuanya melarangnya bermain game mereka merasa kesal, marah dan bahkan ada yang sampai tidak mau makan. ${ }^{3}$ Jenis game yang sering dimainkan anak-

${ }^{2}$ Hasil Observasi di MI NW Gelogor, pada tanggal 16 November 2017.

${ }^{3}$ Hasil Wawancara Beberapa Siswa MI NW Gelogor, Pada Tanggal 16 November 2017. 
anak adalah seperti clas of clans, plant vs zombie, tekken, grand gangster, monet dan lain-lain. Oleh karena itu, peneliti tertarik melakukan penelitian di MI NW Gelogor Kecamatan Kediri. Berdasar pada permasalahan di atas, penelitian ini bertujuan untuk mengetahui bagaimana pengaruh penggunaan game gadget terhadap minat belajar siswa.

\section{LANDASAN TEORI}

\section{Minat Belajar}

Menurut Hurlock, minat adalah sumber motivasi yang mendorong orang untuk melakukan apa yang mereka inginkan bila mereka bebas memilih. ${ }^{4}$ Minat pada dasarnya adalah penerimaan akan suatu hubungan antara diri sendiri dengan sesuatu di luar diri. Semakin kuat atau dekat hubungan tersebut, semakin besar minatnya. Crow and Crow mengatakan bahwa minat berhubungan dengan gaya gerak yang mendorong seseorang untuk menghadapi atau berurusan dengan orang, benda, kegiatan, pengalaman yang dirangsang oleh kegiatan itu sendiri. ${ }^{5}$ Minat merupakan suatu sifat yang relatif menetap pada diri seseorang. Minat ini besar sekali pengaruhnya terhadap belajar sebab dengan minat seseorang akan melakukan.

Dari beberapa pengertian di atas, dapat disimpulkan bahwa minat adalah kecenderungan seseorang terhadap obyek atau sesuatu kegiatan yang digemari yang disertai dengan perasaan senang, adanya perhatian, dan keaktifan berbuat. Minat mengandung unsur kognisi (mengenal), emosi (perasaan), dan konasi (kehendak). Oleh sebab itu, minat dianggap sebagai respon yang sadar, sebab jika tidak demikian, minat tidak akan mempunyai arti apa-apa. Unsur kognisi maksudnya adalah minat itu didahului oleh pengetahuan dan informasi mengenai obyek yang dituju oleh minat tersebut, ada unsur emosi karena dalam partisipasi atau pengalaman itu disertai oleh perasaan tertentu, seperti rasa senang, sedangkan unsur konasi merupakan kelanjutan dari unsur kognisi. Dari ketiga unsur inilah yang diwujudkan dalam bentuk kemauan dan hasrat untuk melakukan suatu kegiatan, termasuk kegiatan yang ada di sekolah seperti belajar.

${ }^{4}$ Elizabeth Hurlock, Perkembangan Anak. Jilid 2, (Jakarta: Erlangga, 2010), hlm. 114.

5Ibid. 


\section{Faktor yang Mempengaruhi Minat Belajar}

Minat belajar siswa menjadi penentu kegiatan belajar siswa. Minat belajar yang besar cenderung menghasilkan prestasi belajar siswa yang tinggi dan sebaliknya minat belajar yang kurang akan menghasilkan prestasi yang rendah. ${ }^{6}$ Banyak faktor yang mempengaruhi minat belajar siswa. Menurut Susanto (dalam Simbolon) faktor yang mempengaruhi minat belajar siswa yaitu: motivasi, keluarga, peranan guru, sarana dan prasarana, temen pergaulan, dan media masa/media elektronik. ${ }^{7}$

Apabila seseorang bergaul dengan orang yang berkepribadian baik tentu orang tersebut akan terpengaruh menjadi baik pula. Begitu pula dalam hal minat, orang yang bergaul dengan orang yang mempunyai minat yang besar dalam belajar tentu orang tersebut juga dapat terpengaruh. Karena teman pergaulan sangat berpengaruh terhadap kepribadian siswa.

\section{Faktor Yang Membangkitkan Minat Belajar}

Pelajaran berjalan lancar bila ada minat. Anak-anak malas dan tidak belajar, gagal karna tidak adanya minat. Menurut Nasution minat dapat dibangkitkan dengan cara-cara berikut: 8 1. Bangkitkan suatu kebutuhan (kebutuhan untuk menghargai keindahan, untuk mendapat penghargaan, dan sebagainya)

2. Hubungkan dengan pengalaman yang lampau.

3. Beri kesempatan untuk mendapat hasil baik, "Nothing succeds like success". Tak ada yang lebih memberi hasil yang baik. Untuk itu bahan pelajaran di sesuikan dengan kesanggupan individu.

4. Gunakan berbagai bentuk mengajar seperti diskusi, kerja kelompok, membaca, demonstrasi, dan sebagainya.

Sedangkan menurut Saefullah siswa terdorong untuk belajar apabila mereka memiliki minat untuk belajar, oleh sebab itu, mengembangkan minat belajar siswa merupakan salah satu teknik dalam mengembangkan motivasi belajar. Berapa cara dapat dilakukan untuk membangkitkan minat belajar siswa, di antaranya sebagai berikut: ${ }^{9}$

${ }^{6}$ M. Dalyono, Psikologi Pendidikan, (Jakarta: Rineka Cipta, 2012), hlm. 57.

${ }^{7 N a e k l a n ~ S i m b o l o n, " F a k t o r-F a k t o r ~ y a n g ~ M e m p e n g a r u h i ~ M i n a t ~ B e l a j a r ~ P e s e r t a ~ D i d i k ", ~ d a l a m ~}$ http//jurnal.unimed.ac.id/2012/index.php/elementary/article/view/1323, diakses tanggal 6 Juni 2018, pukul 10.10 .

${ }^{8}$ Nasution, Dikdaktik Asas-Asas Mengajar...., hlm. 82.

'Saefullah, Psikologi Perkembangan..., hlm. 302. 
1. Menghubungkan bahan pelajaran yang akan diajarkan dengan kebutuhan siswa. Minat siswa akan tumbuh apabila ia dapat menangkap bahwa materi pelajaran itu berguna untuk kehidupannya. Dengan demikian, guru perlu menjelaskan keterkaitan materi pelajaran dengan kebutuhan siswa.

2. Menyesuaikan materi pelajaran dengan tingkat pengalaman dan kemampuan siswa. Materi pelajaran yang terlalu sulit untuk dipelajari atau materi pelajaran yang jauh dari pengalaman siswa, tidak akan diminati oleh siswa. Materi pelajaran yang terlalu sulit tidak akan dapat diikuti dengan baik, yang menyebabkan siswa gagal mencapai hasil yang optimal: dan kegagalan itu dapat membunuh minat siswa untuk belajar. Biasanya minat siswa akan tumbuh kalau ia mendapatkan kesuksesan dalam belajar.

3. Menggunakan berbagai model dan strategi pembelajaran secara bervariasi, misalnya diskusi, kerja kelompok, eksperimen, demonstrasi, dan lain-lain.

Berdasarkan teori di atas, dapat disimpulkan untuk membangkitkan minat belajar siswa terdapat beberapa cara yaitu: menghubungkan materi dengan pengalaman hidup anak atau materi yang akan diajarkan, mebangkitkan kecintaan pada keindahan, menggunakan model dan strategi secara bervariasi.

\section{Indikator Minat Belajar}

Indikator minat belajar merupakan sebuah acuan pengukuran untuk mengetahui minat belajar siswa. Terdapat beberapa indikator minat belajar yang dimiliki siswa dalam proses belajarnya baik di sekolah maupun di rumah. Menurut Zanikhan, indikator minat belajar siswa sebagai berikut: ${ }^{10}$

1. Rasa suka dan ketertarikan terhadap hal yang dipelajari

2. Keinginan siswa untuk belajar

3. Perhatian terhadap belajar

4. Keantusiasan serta partisipasi dan keaktifan siswa dalam belajar.

Berdasarkan yang dikemukakan Djaali dalam bukunya, minat merupakan rasa suka, ketertarikan, keinginan, partisipasi, dan keterlibatan seseorang dengan orang, benda, kegiatan yang dirangsang oleh kegiatan itu sendiri. ${ }^{11}$ Jadi dari pengertian di atas dapat

\footnotetext{
${ }^{10}$ Zanikhan, "Pengertian Minat Belajar", dalam http://zanikhan.multiply.com/journal/item di akses tanggal 3 Desember 2017, pukul 09.24.

${ }^{11}$ Djaali, Psikologi Pendidikan..., hlm. 121-122. 
dijadikan indikator untuk mengukur minat belajar siswa. Rasa suka tampak ketika adanya kegairahan siswa dalam mengikuti pembelajaran. Ketertarikan siswa dapat diukur dari respon atau tanggapan siswa terhadap materi pelajaran. Partisipasi dapat diukur melalui aktivitas siswa. Perhatian dapat diukur apabila siswa memiliki keseriusan selama proses pembelajaran berlangsung. Keterlibatan siswa dapat akan tampak pada saat pembelajaran apakah siswa terlibat secara aktif atau secara pasif.

\section{Intensitas Penggunaan Elektronik Game Gadget}

Kata intensitas berasal dari bahasa Inggris, yaitu intense yang berarti hebat, kuat, bersemangat. ${ }^{12}$ Secara bahasa intensitas berarti keadaan tingkat ukuran intensnya (Kamus Besar Bahasa Indonesia). ${ }^{13}$ Sedangkan menurut Hazim intensitas adalah kebulatan tenaga yang dikerahkan untuk suatu usaha. Jadi intensitas secara sederhana dapat dirumuskan sebagai suatu usaha yang diluangkan oleh seseorang dengan penuh semangat untuk mencapai tujuan. ${ }^{14}$

Dari beberapa pemaparan di atas, dapat disimpulkan intensitas adalah kualitas dari tingkat kedalaman yang meliputi kemampuan, daya konsentrasi terhadap sesuatu, tingkat keseringan dan kedalaman cara atau sikap seseorang pada objek tertentu. Intensitas dapat dilihat dengan mengetahui tingkatan keseringan (frekuensi) dan durasi yang nampak ketika melakukan suatu hal. Tingkatan frekuensi nampak pada ukuran berapa kali seorang dalam melakukan sesuatu. Durasi nampak pada seberapa seseorang dalam melakukan sesuatu. Jadi intensitas dapat di artikan sebagai sebeberapa sering, ukuran, tingkat, dan waktu seseorang menggunakan suatu objek tersebut.

Intensitas penggunaan game gadget merupakan tingkat keseringan (frekuensi) seseorang dalam menggunakan game gadget. Penggunaan game gadget saat ini perlu diperhatikan secara khusus. Penggunaan game gadget yang berlebihan dapat mengakibatkan kerugian bagi penggunanya. Kerugian tidak hanya pada kesehatan saja, melainkan kerugian dalam segi ekonomi, karakter, dan pendidikan. Khususnya pada anak-anak penggunaan game gadget

${ }^{12} J o h n$ M. Echols \& Hassan Shadily, Kamus Inggris Indonesia, (Jakarta: Gramedia Pustaka Utama, 1996), hlm. 326.

${ }^{13}$ Depertemen Pendidikan Nasional, Kamus Besar Bahasa Indonesia, (Jakarta: Balai Pustaka, 2002), hlm. 438.

${ }^{14}$ Scribd, "Pengertian intensitas". dalam https://www.scribd.com/doc/316536693/ PengertianIntensitas, diakses tanggal 6 juni 2018, pukul 9:35. 
dapat berpengaruh terhadap minat belajar anak. Intensitas penggunaan game gadget pada anak-anak dikelompokan sebagai berikut: ${ }^{15}$

1. Pagi sebelum sekolah, ketika anak bangun dari tidurnya anak akan lebih dulu mencari gadget-nya. Dan meluangkan waktunya bermain game gadget sebelum berangkat sekolah

2. Anak setelah sekolah, ketika waktu di sekolah anak akan lebih memikirkan/melamun tentang game yang telah dia mainkan. Sehingga ketika dia pulang dari sekolahnya anak akan mencari gadget-nya langsung.

3. Sore hari, anak lebih sering bermain game gadget pada sore hari waktu istirahat, dan sering kumpul bersama temen-temennya.

4. Malam hari sebelum/sesudah belajar, anak akan lebih sering meluangkan waktunya pada malam hari untuk bermain game gadget, bahkan anak akan mengabaikan waktu belajarnya, karna rasa penasaran dengan permainan yang ada di gadgetnya.

5. Pagi, siang, sore, malam pada saat libur sekolah, jadi pada saat libur skolah anak lebih sering menghabiskan waktunya bermain game gadget dari pada kumpul/liburan sama teman/keluarganya.

\section{Game Gadget}

Perkembangan teknologi khususnya perkembangan gadget memberikan dampak terhadap kehidupan manusia. Kepemilikan barang tersebut sudah sampai ke tangan masyarakat segala usia. Gadget adalah sebuah istilah dalam bahasa Inggris yang mengartikan sebuah alat elektronik kecil dengan berbagai macam fungsi. Menurut Osland (dalam Novitasari), Gadget sendiri dapat berupa komputer atau laptop, tablet PC, dan juga telepon seluler atau smartphone. ${ }^{16}$ Gadget memiliki banyak fungsi bagi penggunanya sehingga dinilai lebih memudahkan.

Gadget memiliki perbedaan dengan perangkat elektronik lainnya. Perbedaan yang dimaksud adalah adanya unsur kebaruan pada gadget. Artinya, dari waktu ke waktu gadget selalu menyajikan teknologi terbaru yang membuat hidup semakin praktis. Kebanyakan dari anak-anak menggunakan gadget berjenis smartphone maupun tablet PC. Anak-anak lebih sering

${ }^{15}$ Yusufhadi Miarso, Menyamai Benih Teknologi Pendidikan, (Jakarta: Kecana, 2004), hlm. 421.

16Wahyu Novitasari, "Dampak Penggunaan Gadget Terhadap Intraksi Sosial Anak Usia 5-6 Tahun", Vol. 5, Nomor 3, Tahun 2016, hlm. 1. 
menggunakan gadget untuk mengoperasikan aplikasi permainan/game, baik itu permainan yang bersifat edukatif maupun petualangan dan hiburan. ${ }^{17}$

Game merupakan aktivitas yang dilakukan untuk hiburan atau menyenangkan yang memiliki aturan sehingga ada yang menang dan kalah (Kamus Besar Bahasa Indonesia). Menurut Wikipedia menyatakan bahwa : "video game is an electronic game that involves human interaction with a user interface to generate visual feedback on a video device. (game adalah sebuah permainan elektronik yang melibatkan interaksi antara pemain dengan interface game untuk menghasilkan efek umpan balik secara visual pada perangkat video). ${ }^{18}$ Menurut bahasa, game berasal dari bahasa Inggris yang artinya permainan. Dalam bahasan ini, permainan adalah sebuah video yang dapat dimainkan oleh pemain melalui alat permainan seperti gadget, komputer atau laptop dan konsol seperti Playstation, Xbox 360, Nintendo Wii dan sebagainya. Permainan tersebut melibatkan interaksi dengan pemain agar dapat menimbulkan efek visual seperti umpan balik dari permainan yang mereka mainkan.

Berdasarkan pemaparan di atas, maka dapat disimpulkan game gadget adalah suatu alat yang berbentuk minimalis seperti smartphone, laptop, dan tablet PC, yang dibuat berdasarkan prinsip elektronika yang digunakan untuk bermain game yang dapat memberikan umpan balik pada pemainnya.

\section{Dampak Bermain Game Gadget Terhadap Anak}

Ada beberapa dampak yang ditimbulkan akibat bermain game gadget. Menurut Rokhani diantaranya: penglihatan anak terganggu, sosialisasi anak kurang, sikap dan prilaku anak berubah, berpengaruh pada kinerja otak, prestasi belajar menurun, bahaya radiasi dari gadget, menjadi sosok yang individualis. ${ }^{19}$ Selanjutnya di jelaskan sebagai berikut:

1. Penglihatan anak terganggu

Setiap kali anak bermain game melalui gadget, maka interaksi antara mata dengan gadget pun semakin sering. Biasanya, jarak antara mata anak dan layar gadget pun sangat dekat. Hal inilah yang memberikan dampak negatif bagi penglihatan anak. Jika proses ini berlangsung lama maka dapat menimbulkan gangguan pada mata, misalnya kerusakan

${ }^{17}$ Ibid., hlm. 2.

${ }^{18}$ Wikipedia, (Last Modified 2013). "Video Game", dalam http://en.wikipedia.org/wiki/Video_game, diakses 28 November 2017, pukul 21.14

19Siti Rokhani,'Dampak Bermain Game Gadget Terhadap Anak", dalam http//dokteranak.org/dampak-negatif-bermain-game-untuk-anak, diakses tanggal 6 Juni 2018, pukul 20.15 .

176 Copyright @ el-Midad : Jurnal PGMI 2019 
saraf pada mata, rabun jauh, atau rabun dekat. Untuk itu akan lebih baik jika orang tua selalu membatasi waktu bermain anak, dan selalu mengawasi sikap anak selama bermain game.

2. Sosialisasi anak kurang

Anak yang sudah merasa nyaman bermain game melalui gadget akan merasa malas untuk bermain di luar. Mereka akan memilih di dalam rumah dan menghabiskan waktu bersama gadget mereka. Akibatnya, mereka akan tumbuh menjadi anak yang tidak nyaman ketika berinteraksi dengan orang lain. Mereka lebih memilih berinteraksi dengan benda mati (gadget) daripada teman-teman sebayanya. Anak-anak yang kecanduan game akan menjadi kurang cakap dalam bersosialisasi dengan lingkungan sekitar.

3. Sikap dan perilaku anak berubah

Dampak selanjutnya dari bermain game pada anak adalah kondisi psikologis anak tersebut. Hal-hal yang terjadi dalam game akan berpengaruh terhadap kebiasaan anak. Misalnya, dalam game tersebut mengandung konten kekerasan yang dilakukan secara berulang, sehingga membuat anak mulai terbiasa melihat kekerasan, maka dalam dunia nyata bukan tidak mungkin mereka akan melakukan hal yang sama. Anak juga dapat menjadi lebih agresif dan mau menang sendiri.

4. Berpengaruh pada kinerja otak anak

Berdasarkan penelitian, masalah kinerja otak yang sering dijumpai pada anak pecandu game adalah masalah konsentrasi. Anak akan selalu merasa senang ketika bermain game, dan hal ini berakibat adanya perubahan struktur dendrit sel-sel di otak. Permasalahan sel ini pada akhirnya berpengaruh pada kemampuan anak dalam mengontrol perilaku dan kemampuan konsentrasinya dalam jangka panjang. Saat konsentrasi anak menurun, maka ia juga akan mudah lupa dan gagal fokus.

5. Prestasi belajar menurun

Pada poin sebelumnya telah dijelaskan bahwa bermain game dapat berakibat si anak menjadi kurang bisa konsentrasi, mudah lupa, dan gagal fokus. Bayangkan jika gangguan ini berlangsung selama proses pembelajaran di sekolah. Alhasil, si anak akan 
kesulitan memahami dan mengikuti pembelajaran yang diberikan oleh guru. Dan pada akhirnya minat belajar dan prestasi belajar di sekolah akan menurun.

6. Bahaya radiasi dari gadget

Setiap gadget atau perangkat elektronik memancarkan radiasi. Radiasi ini sangat berbahaya bagi tubuh jika terpapar dalam jangka waktu yang lama. Paparan radiasi dari perangkat elektronik ini dapat berakibat pada kelemahan konsentrasi anak. Dampak terburuk adalah terganggunya jaringan otak anak akibat radiasi dari gadget atau perangkat elektronik yang biasa digunakan oleh anak.

7. Menjadi sosok anak yang individualis

Anak yang kecanduan bermain game berpotensi memiliki sikap individual dalam dirinya. Sikap individual adalah sikap yang selalu mementingkan diri sendiri, tidak ada kepekaan atau empati terhadap apa pun yang terjadi dengan orang lain. Sikap ini muncul karena kebiasaan anak yang selalu menyendiri untuk bermain game. Akibatnya, anak tidak belajar pentingnya tolong menolong dan kebersamaan bersama teman sebaya.

\section{METODE PENELITIAN}

Jenis penelitian yang digunakan dalam penelitian ini adalah penelitian kuantitatif. Menurut Carmines dan Zeller (dalam Sangadji dan Sopiah), penelitian kuantitatif adalah penelitian yang datanya dinyatakan dalam angka dan dianalisis dengan teknik analisis. Dan metode pendekatan dalam penelitian ini adalah ex-post facto. Metode ex-post facto adalah penelitian dimana variabel-variabel bebas telah terjadi ketika peneliti mulai dengan pengamatan variabel terikat dalam suatu penelitian. ${ }^{20}$ Dalam penelitian ini suatu keterikatan antar variabel maupun antara variabel bebas dengan variabel terikat sudah terjadi secara alami. $^{21}$

\section{Populasi dan Sampel}

Populasi adalah wilayah generalisasi yang terdiri atas subyek atau obyek dengan kualitas dan karakteristik tertentu yang ditetapkan oleh peneliti untuk dipelajari dan kemudian ditarik kesimpulan. Populasi bisa berupa manusia, tumbuhan, hewan, produk, bahkan

\footnotetext{
${ }^{20}$ Etta Mamang Sangadji \& Sopiah, Metodelogi Penelitian Pendekatan Praktis Dalam Penelitian, (Yogyakarta: Andy, 2010), hlm. 26

${ }^{21}$ Ibid., hlm. 25.

178 Copyright $\odot$ el-Midad : Jurnal PGMI 2019
} 
dokumen. ${ }^{22}$ Berdasarkan penjelasan di atas, maka populasi dalam penelitian ini adalah seluruh siswa kelas V MI NW Gelogor tahun pelajaran 2017/2018 yang berjumlah 26 siswa.

Sesuai dengan teori yang mengatakan "Apabila jumlah populasi siswa relatife kecil atau kurang dari 30, maka semua anggota populasi dijadikan sampel. Di mana dalam teknik sampling dinamakan sampling jenuh atau istilah lainnya adalah sensus. Sampling jenuh adalah teknik penentuan sampel bila semua anggota populasi digunakan sebagai sampel. ${ }^{23}$

Berdasarkan uraian di atas, maka yang menjadi sampel dari penelitian ini adalah semua siswa kelas V MI NW Gelogor Tahun Pelajaran 2017/2018.

\section{Waktu dan Tempat Penelitan}

Pelaksanaan kegiatan penelitian dilakukan mulai bulan September 2017- Maret 2018. Penelitian ini dilaksanakan di MI NW Gelogor yang beralamat di Desa Gelogor, Jln. TGKH. Abdul Karim, Kec.Kediri, Lombok Barat, NTB.

\section{Instrumen Penelitian}

Instrumen adalah alat bantu pada waktu penelitian menggunakan suatu metode. Menurut Sugiyono, instrumen penelitian adalah suatu alat yang digunakan mengukur fenomena alam maupun sosial yang diamati. Secara spesifik semua fenomena ini disebut variabel penelitian. ${ }^{24}$ Jadi, instrumen dalam penelitian ini menggunakan instrumen penelitian berupa angket (kuesioner). Angket digunakan dalam penelitian ini untuk mendapatkan data intensitas penggunaan game gadget dan minat belajar siswa.

Pengukuran angket menggunakan skala Likert. Menurut Kinner (dalam Umar), Skala Likert ini berhubungan dengan pernyataan tentang sikap seseorang terhadap sesuatu, misalnya setuju tidak setuju, senang tidak senang, dan baik tidak baik. ${ }^{25}$ Jawaban setiap item instrumen yang menggunakan skala Likert ini mempunyai tingkatan dari sangat positif sampai sangat negatif. Setiap pernyataan jawaban pada angket berisi empat alternatif jawaban yaitu Selalu (SL), Sering (SR), kadang-kadang (KD), dan Tidak Pernah (TP). ${ }^{26}$

\footnotetext{
22Ibid., hlm. 185.

${ }^{23}$ Ibid., hlm. 189.

${ }^{24}$ Sugiyono, Metode Penelitian ..., hlm. 102.

${ }^{25}$ Husein Umar, Metode Penelitian..., hlm. 70.

${ }^{26}$ Sugiyono, Metode Penelitian ..., hlm. 93.
} 
Sebelum menetapkan pilihan dan menyusun instrumen, perlu diuji validitas dan reliabilitasnya. Karna perskoran kedua instrumen sama, maka rumus uji validitas dan reliabilitas yang akan digunakan adalah sama. Uji validitas dalam penelitian ini dilakukan dengan bantuan program komputer. Butir pernyataan pertama dihitung secara manual dan butir pernyataan selanjutnya dianalisis menggunakan bantuan microsof excel dengan rumus pearson product moment. Setelah dilakukan perhitungan akan mengetahui butir pernyataan tersebut valid atau tidak valid dengan pedoman jika rhitung $\geq$ rtabel pada signifikan 5\% maka butir pernyataan valid. Jika rhitung $\leq$ rtabel maka butir soal tidak valid. Karna n=20 r table yang digunakan peneliti adalah $(0,444)$ sebagai perbandingan $r$ hitung pada uji validitas. Uji coba instrumen penelitian ini dilakukan pada 20 siswa kelas V MI NW Dasan Agung dengan lembar angket/kuesioner variabel intensitas penggunaan game gadget berjumlah 20 butir pertanyaan, lembar angket/kuesioner variabel minat belajar 20 butir pertanyaan.

Berdasarkan hasil uji coba yang dilakukan dengan menggunakan rumus Alpa Cronbach, sehingga diperoleh $\mathrm{r}$ hitung intensitas penggunaan elektronik game gadget adalah 0,875 dan r hitung minat belajar adalah 0.856 . Berdasarkan interprestasi kofisien reliabilitas kedua data tersebut reliabel dengan kategori reliabilitas sangat tinggi.

\section{Teknik Pengumpulan data}

Teknik pengumpulan data adalah prosedur yang sistematis dan standar untuk memperoleh data yang diperlukan. ${ }^{27}$ Dalam penelitian ini digunakan dua teknik pengumpulan data yaitu: angket (untuk mengukur minat belajar dan intensitas penggunaan game gadget), observasi (untuk memperoleh informasi pra penelitian), dokumentasi (untuk memperoleh data sekolah).

\section{Teknik Analisis Data}

Dalam penelitian ini data yang sudah diperoleh akan dideskripsikan menggunakan statistik deskriptif. "Statistik deskriptif adalah statistik yang digunakan untuk menganalisis data dengan cara mendeskripsikan atau menggambarkan data yang telah terkumpul sebagaimana adanya tanpa bermaksud membuat kesimpulan yang berlaku untuk umum

${ }^{27}$ Moh. Nazir, Metode Penelitian...,hlm. 153. 
atau generalisasi". ${ }^{28}$ Statistik deskriptif menggambarkan proses rata-rata (mean), modus, median, simpangan baku, dan distribusi frekuensi suatu data.

\section{Uji Prasyarat}

\section{Uji Normalitas}

Uji normalitas dilakukan untuk mengetahui apakah data yang diambil berasal dari populasi yang berdistribusi normal atau tidak. Untuk tes normalitas data, peneliti menggunakan rumus chi square. Kriteria: jika $\chi_{\text {hitung }}^{2}<\chi_{\text {tabel }}^{2}$, maka data berdistribusi normal. Pada keadaan lain, tidak berdistribusi normal, pada taraf signifikan 5\%.

\section{Uji signifikan dan uji linearitas}

Uji signifikan dilakukan untuk mengetahui apakah regresi liniear sederhananya berarti/bermakna. Uji signifikan dilakukan dengan uji F. Jika $\mathrm{F}$ hitung $>\mathrm{F}$ tabel pada taraf

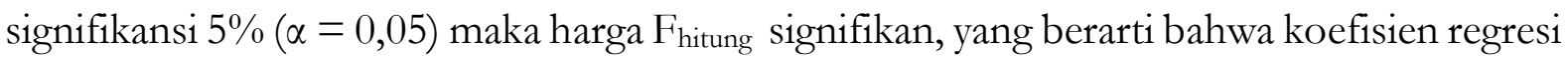
adalah berarti atau bermakna, yang berarti bahwa hipotesis nol ditolak dan hipotesis alternatif diterima. Jika harga $\mathrm{F}_{\text {hitung }}<\mathrm{F}_{\text {tabel, }}$, maka harga $\mathrm{F}_{\text {hitung }}$ non signifikan, yang berarti bahwa hipotesis nol diterima dan hipotesis alternatif ditolak.

Uji linieritas bertujuan untuk mengetahui apakah data yang akan dikorelasikan itu regresinya liniear atau non linear. Jika $\mathrm{F}$ hitung $<\mathrm{F}$ tabel pada taraf signifikansi $5 \%(\alpha=0,05)$ maka Ho ditolak, yang berarti bahwa data berpola linear dan jika $F$ hitung $>F$ tabel pada taraf signifikansi 5\% $(\alpha=0,05)$ maka Ho diterima, yang berarti bahwa data berpola tidak linear.

\section{Uji Hipotesis}

Hipotesis merupakan suatu jawaban bersifat sementara terhadap permasalahan penelitian sampai terbukti melalui data yang terkumpul. Dalam pembuktian, hipotesis $\mathrm{Ha}$ diubah menjadi Ho agar peneliti tidak mempunyai perasangka. Jadi, peneliti diharapkan jujur dan tidak terpengaruh pernyataan $\mathrm{Ha} .{ }^{29}$ Kemudian, hipotesis dikembangkan lagi ke Ha pada rumusan akhir pengetesan hipotesis. Untuk menguji hipotesis yang menyatakan bahwa terdapat pengaruh intensitas penggunaan game gadget terhadap minat belajar siswa

${ }^{28}$ Sugiyono, Metode Penelitian..., hlm. 147

${ }^{29}$ Etta Mamang Sangadji \& Sopiah, Metodelogi Penelitian..., hlm. 92. 
digunakan teknik analisis regresi linear sederhana, adapun rumus yang digunakan adalah $\hat{Y}=$ a + bX, dan untuk menghitung a dan b di peroleh dari hasil pengamatan $\mathrm{X}$ dan $\mathrm{Y}$.

Untuk mengetahui koefisien korelasinya menggunakan rumus product moment. Analisis korelasi berguna untuk menentukan suatu besaran yang menyatakan bagaimana kuat hubungan/pengaruh suatu variabel dengan variabel lainnya. Koefisien korelasi juga memperlihatkan arah dan kuatnya korelasi antar variabel yang diteliti. Untuk korelasi antara $\mathrm{X}$ dan $\mathrm{Y}$ hanya dapat dipertanggungjawabkan apabila didasari oleh regresi $\mathrm{X}$ atas $\mathrm{Y}$. Berpangkal pada pengertian tersebut korelasi (r) dapat dihitung dengan menggunakan rumus korelasi product moment,

Untuk mengetahui seberapa besar koefisien determinasi (KD) variabel X terhadap variabel Y digunakan rumus sebagai berikut: ${ }^{30}$

$$
K D\left(r^{2}\right)=r^{2} \times 100 \%
$$

Dan untuk mengetahui signifikansi koefisien korelasinya digunakan rumus fungsi statistik sebagai berikut: ${ }^{31}$

$$
t_{\text {hitung }}=\frac{r \sqrt{n-2}}{\sqrt{1-r^{2}}}
$$

Jika thitung $>t_{\text {tabel }}$ pada taraf signifikansi $5 \%(\alpha=0,05)$ uji dua pihak maka harga thitung koefisien korelasi signifikan, yang berarti bahwa hipotesis nol ditolak dan hipotesis alternatif diterima. Jika harga $\mathrm{t}_{\text {hitung }}<\mathrm{t}_{\text {tabel, }}$, maka harga $\mathrm{t}_{\text {hitung }}$ non signifikan, yang berarti bahwa hipotesis nol diterima dan hipotesis alternatif ditolak.

\section{HASIL PENELITIAN DAN PEMBAHASAN}

\section{Hasil Penelitian}

\section{Interpretasi Data Penggunaan Game Gadget}

Berdasarkan data yan terkumpul dapat diketahui bahwa intensitas penggunaan game gadget siswa kelas V MI NW Gelogor yang tergolong tinggi sebanyak 8 siswa $(30,77 \%)$, tergolong sedang sebanyak 14 siswa (53,85\%), dan yang tergolong rendah sebanyak 4 siswa

${ }^{30}$ Subana, dkk, Statistik Pendidikan..., hlm. 145.

${ }^{31}$ Sugiyono, Metode Penelitian..., hlm. 184. 
(15,38\%). Sehingga dapat disimpulkan bahwa intensitas bermain game gadget siswa adalah sedang. Penyajian data dalam histogram sebagai berikut:

\section{Gambar 1}

Histogram Intensitas Penggunaan Game Gadget

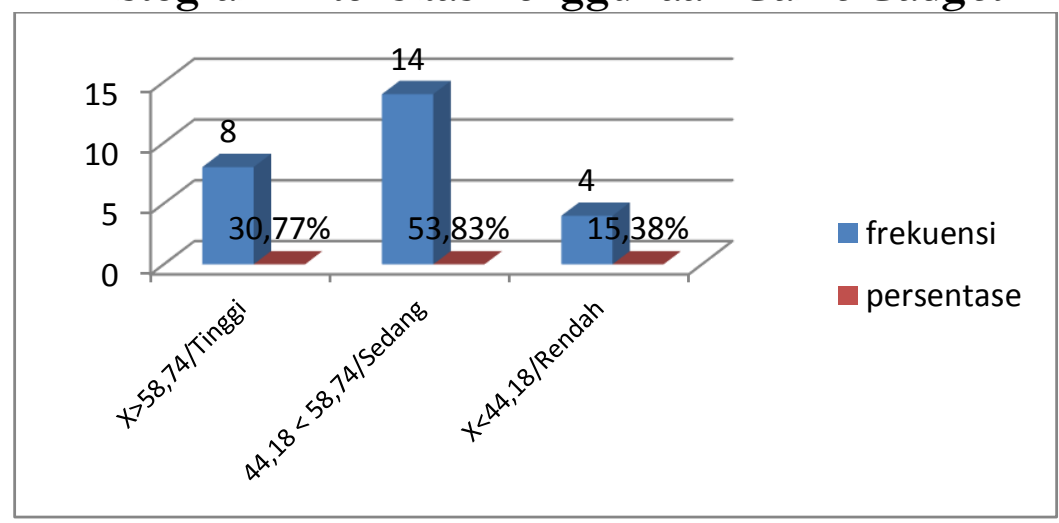

\section{Interpretasi Data Minat Belajar Siswa}

Berdasarkan data yang terkumpul dapat diketahui bahwa minat belajar siswa kelas $\mathrm{V}$ MI NW Gelogor yang tergolong tinggi sebanyak 7 siswa (26,92\%), tergolong sedang sebanyak 15 siswa $(57,69 \%)$, dan yang tergolong rendah sebanyak 4 siswa $(15,38 \%)$ sehingga dapat disimpulkan bahwa minat belajar siswa adalah sedang. Data digambarkan dalam histogram sebagai berikut:

\section{Gambar 2}

Histogram Minat Belajar Siswa

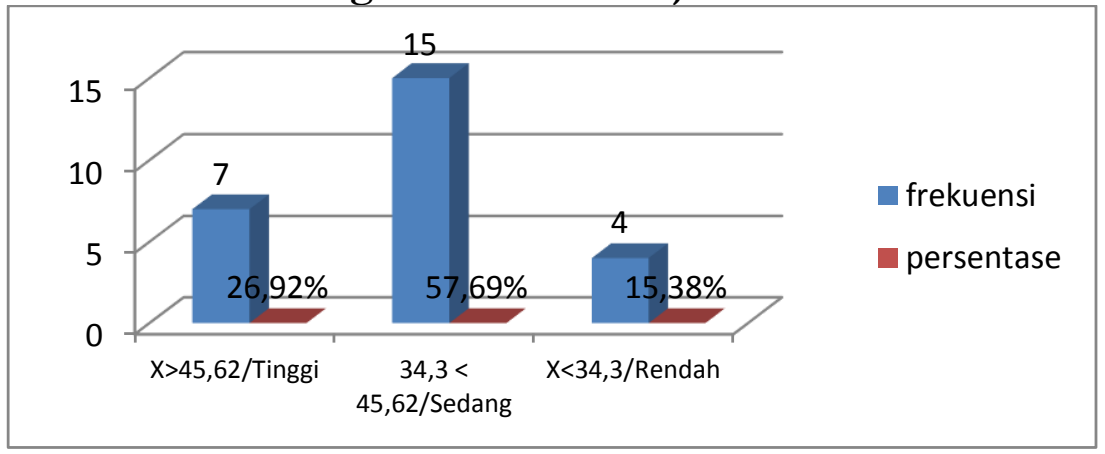

\section{Uji Normalitas}

Uji normalitas data dilakukan untuk mengetahui data pada setiap variabel berdistribusi normal atau tidak normal. Uji normalitas dilakukan pada variabel intensitas penggunaan game gadget $(\mathrm{X})$, dan variabel minat belajar (Y). Uji Normalitas dilakukan dengan 
menggunakan rumus chi square/chi kuadrat. Dengan taraf signifikan 5\%, dengan kriteria jika $\chi_{\text {hitung }}^{2} \geq \chi_{\text {tabel }}^{2}$ maka data tidak berdistribusi normal dan jika $\chi_{\text {hitung }}^{2}<\chi_{\text {tabel }}^{2}$ maka data berdistribusi normal. Hasil uji normalitas dapat dilihat pada tabel berikut; 32

\section{Tabel 3}

Ringkasan Hasil Uji Normalitas

\begin{tabular}{ccccc}
\hline No & Variabel & $\chi_{\text {hitung }}^{2}$ & $\chi_{\text {tabel }}^{2}$ & Keterangan \\
\hline 1 & $\begin{array}{c}\text { Intensitas Penggunaan Elektronik } \\
\text { Game Gadget }\end{array}$ & 1,84 & 7,81 & Normal \\
\hline 2 & Minat Belajar & 0,88 & 7,81 & Normal \\
\hline
\end{tabular}

Berdasarkan tabel di atas dapat disimpulkan bahwa hasil perhitungan $\chi_{\text {hitung }}^{2}$ lebih kecil dari $\chi_{\text {tabel }}^{2}$, maka kedua data tersebut berdistribusi normal. Sehingga analisis statistik parametrik dapat digunakan dalam analisis penelitian.

\section{Uji Liniaritas}

Sebelum analisis regresi sederhana digunakan maka data terlebih dahulu akan diuji linieritasnya. Berdasarkan hasil uji linearitas diperoleh $F_{\text {hitung }}$ sebesar 1,54 dengan $F_{\text {tabel }}$ sebesar 3,01. Dengan keriteria; jika $F_{\text {hitung }}<\mathrm{F}_{\text {table }}$ maka Ho ditolak yang artinya data berpola linear. Jika $F_{\text {hitung }}>F_{\text {table }}$ maka Ho diterima yang artinya data berpola tidak linear. karna $F_{\text {hitung }}(1,54)<\mathrm{F}_{\text {table }}(3,01)$ maka Ho ditolak yang artinya data berpola linear.

2. Keberartian regresi linear sederhana/signifikansinya

Untuk mengetahui keberartian regresi linier sederhana digunakan rumus fungsi $\mathrm{F}$ statistik dengan langkah-langkah sehingga diperoleh nilai $\mathrm{F}_{\text {hitung }}=15,836$ dan $\mathrm{F}_{\text {tabel }}=(\alpha ; \mathrm{k} ; \mathrm{n}$ $\mathrm{k}-1)=(0,05 ; 1 ; 26-1-1)=(0,05 ; 1 ; 24)=4,26.33$ Dengan kriteria $:$ jika $F_{\text {hitung }}>\mathrm{F}$ table maka Ho di tolak dan Ha diterima yang artinya koefisien arah regresi berarti/signifikan. karna $F_{\text {hitung }}$ $(15,84)>F_{\text {table }}(4,26)$ maka Ho di tolak dan Ha diterima yang artinya koefisien arah regresi berarti/signifikan. 


\section{Pengujian Hipotesis}

1. Hasil Regresi Linear Sederhana

Menghitung nilai a dan b

Berdasarkan hasil perolehan nilai $\mathrm{a}=63,94$ dan $\mathrm{b}=-0,46$ nilai-nilai tersebut dimasukkan ke dalam rumus regresi linier yaitu:

$$
\hat{Y}=a+b \mathrm{X}
$$

a : Nilai koefisien konstanta

b : Nilai koefisien regresi

Sehingga persamaan di atas menjadi: $\mathrm{Y}=63,94-0,46 \mathrm{X}$.

Berdasarkan persamaan di atas diketahui nilai konstantanya sebesar 63,94. Secara matematis, nilai konstanta ini menyatakan bahwa pada saat intensitas penggunaan game gadget 0 , maka minat belajar siswa memiliki nilai 63,94.

Selanjutnya nilai negatif $(-0,46)$ yang terdapat pada koefisien regresi variabel bebas (intensitas penggunaan game gadget) menggambarkan bahwa arah hubungan antara variabel bebas (intensitas penggunaan game gadget) dengan variabel terikat (minat belajar siswa) adalah tidak searah, dimana setiap kenaikan satu satuan variabel intensitas penggunaan game gadget akan menyebabkan penurunan minat belajar siswa sebesar -0,46.

\section{Koefisien Korelasi}

Untuk menghitung koefisien korelasi antara hasil angket intensitas penggunaan game gadget $(\mathrm{X})$ dengan minat belajar siswa $(\mathrm{Y})$ ditentukan menggunakan rumus korelasi product moment $(\mathrm{r})$. Sehingga diperoleh nilai $\mathrm{r}_{\text {hitung }}=-0,63081$ (berkorelasi negatif signifikan kategori kuat).

Untuk mengetahui signifikansi koefisien korelasinya diuji menggunakan rumus t dengan uji dua pihak sebagai berikut:

$$
t_{\text {hitung }}=\frac{r \sqrt{n-2}}{\sqrt{1-r^{2}}}=\frac{-0,63081 \sqrt{26-2}}{\sqrt{1-(-0,63081)^{2}}}=-3,982
$$

Nilai $t_{\text {hitung }}$ tersebut selanjutnya dibandingkan dengan $t_{\text {tabel }}$ Untuk signifikan $5 \%$ uji dua pihak $\mathrm{dk}=26-2=24$, maka diperoleh $t_{\text {tabel }}=2,064$. Hal ini dapat di gambarkan seperti berikut: 


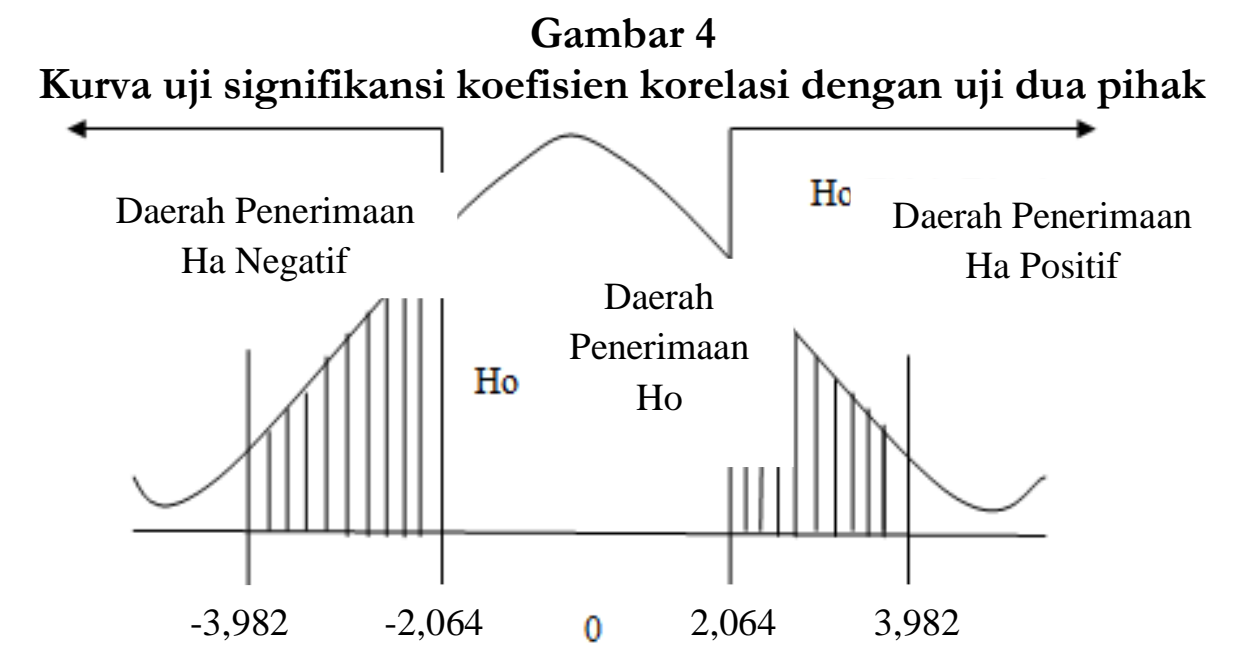

Berdasarkan perhitungan dan yang ditunjukan pada gambar di atas, maka dinyatakan bahwa $t_{\text {hitung }}$ jatuh pada daerah penerimaan Ha negatif, maka dapat dinyatakan Ho ditolak dan Ha diterima. Jadi kesimpulannya koefisien korelasi antara intensitas penggunaan game gadget terhadap minat belajar siswa berkorelasi negatif signifikan dengan kategori kuat.

Kemudian untuk mengetahui konstribusi variabel intensitas penggunaan game gadget (X) dengan minat belajar siswa $(\mathrm{Y})$ digunakan rumus koefisien determinansi (KD). Sehingga diperoleh nilai koefisien determinansi $(\mathrm{KD})=0,397927 \times 100 \%=40 \%$. Jadi, konstribusi variabel intensitas penggunaan game gadget $(\mathrm{X})$ dengan minat belajar siswa $(\mathrm{Y})$ sebesar $40 \%$.

\section{Pembahasan}

Berdasarkan hasil uji hipotesis yang telah diuraikan di atas, diperoleh hasil bahwa variabel $(\mathrm{X})$ intensitas penggunaan game gadget berpengaruh signifikan terhadap variabel $(\mathrm{Y})$ minat belajar siswa kelas V MI NW Gelogor. Hal tersebut ditunjukkan dari hasil analisis korelasi product moment sebesar -0,63081 yang berarti memiliki pengaruh negatif signifikan. Hal ini dibuktikan dengan hasil perhitungan uji t sebesar -3,982, sedangkan pada t tabel adalah 2,064 pada taraf signifikansi 5\% yang berarti bahwa Ha diterima yaitu : Terdapat pengaruh intensitas penggunaan game gadget terhadap minat belajar siswa kelas $\mathrm{V}$ MI NW Gelogor tahun pelajaran 2017/2018, dan menolak Ho, yaitu: Tidak terdapat pengaruh intensitas penggunaan game gadget terhadap minat belajar siswa kelas V MI NW Gelogor tahun pelajaran 2017/2018,

Dengan koefisien determinasi sebesar 39,79 (dibulatkan menjadi 40) atau 40\% berpengaruh negatif, artinya jika semakin sering anak bermain game gadget maka minat belajar anak akan menurun. Sedangkan 60\% merupakan faktor yang mempengaruhi variabel Y dari faktor lain yang tidak diteliti oleh peneliti. Yang tidak diteliti diantaranya 186 Copyright $\odot$ el-Midad : Jurnal PGMI 2019 
faktor kepribadian, faktor teman sebaya, faktor motivasi dan keluarga. Sejalan dengan yang dikemukakan oleh Susanto (dalam Simbolon) faktor-faktor yang mempengaruhi minat belajar siswa di antaranya: keluarga, peranan guru, sarana dan prasarana, teman pergaulan dan media massa/media elektronik. ${ }^{34}$

Sarana prasarana dan media massa/media elektronik merupakan beberapa faktor yang mempengaruhi minat belajar siswa baik di lingkungan sekolah atau rumahnya. Menurut Djamarah minat merupakan perasaan yang didapat karena berhubungan dengan sesuatu. Minat terhadap sesuatu itu dipelajari dan dapat mempengaruhi minat-minat baru. ${ }^{35}$ Dari yang dikemukakan oleh Djamarah, ini berarti ketika anak lebih meminati game gadget dari pada belajarnya, anak-anak akan lebih sering bermain game dari pada belajar. Hal ini dapat mempengaruhi minat dan waktu belajar anak, sehingga waktu belajar anak-anak di rumah akan berkurang karena dibagi dengan waktu bermain game gadget yang lebih menyenangkan.

Minat seorang anak juga dapat dipengaruhi oleh temen sebaya/pergaulan. Sejalan dengan yang dikemukakan oleh Hurlock bahaya yang bersumber pada penerimaan minat teman sebaya sebagai minat sendiri. Pertama, anak-anak mungkin mengembangkan minat yang tidak sesuai kemampuan mereka sendiri, akibatnya minat ini tidak memenuhi kebutuhan mereka. Jika anak bergaul dengan seseorang yang sering bermain game hal ini dapat mempengaruhi minat belajarnya, anak-anak akan mengikuti minat teman sebayanya yang tidak sesuai dengan minatnya sendiri, bahkan anak-anak akan ikut juga bermain game hal ini membuat kebutuhan belajar anak-anak jadi berkurang, Kedua, membiarkan teman sebaya mempengaruhi minat mengakibatkan perkembangan sikap yang tidak menguntungkan terhadap minat yang lebih sesuai dengan kemampuan anak dan yang akan memenuhi kebutuhannya dengan lebih baik. Ketiga, mengembangkan minat yang tidak sesuai dengan kemampuan, karna pengaruh teman sebagai mengakibatkan anak itu akan kurang berhasil dibandingkan bila mereka memanfaatkan waktu dan tenaga untuk kegiatan yang sesuai dengan minat mereka. Ketika anak lebih sering bermain game gadget dari pada belajar, ini dapat mempengaruhi minat belajarnya, anak-anak akan jadi lebih malas,

${ }^{34}$ Naeklan Simbolon,"Faktor-Faktor yang Mempengarubi Minat Belajar Peserta Didik", dalam http//jurnal.unimed.ac.id/2012/index.php/elementary/article/view/1323, diakses tanggal 6 juni 2018, pukul 10.10 .

${ }^{35}$ Syaiful Bahri Djamarah, Psikologi Belajar..., hlm. 167. 
menyendiri, tertutup bahkan belajar anak-anak akan berkurang saat di rumahnya. ${ }^{36}$ Bahkan ketika anak belajar di sekolahnya anak akan mengalami penurunan minat belajarnya yang ditunjukan melalui ketika belajar anak melamun, tidak memperhatikan, mengantuk, berbicara dengan teman sebangku, ingin cepat pulang dan lain-lain.

Hal ini dapat dilihat dari hasil analisis regresi liniear sederhananya diperoleh persamaan regresi $\mathrm{Y}=63,94-0,46 \mathrm{X}$. Persamaan tersebut sesuai dengan rumus regresi linier sederhana yaitu $\mathrm{Y}=\mathrm{a}+\mathrm{bX}$, dimana $\mathrm{Y}$ merupakan lambang dari variabel terikat, a konstanta, $\mathrm{b}$ koefisien regresi untuk variabel bebas $(\mathrm{X})$ dan tanda negatif (-) merupakan arah pengaruhnya.

Konstanta sebesar 63,94: artinya jika intensitas penggunaan game gadget (X) nilainya adalah 0, maka minat belajar siswa (Y) nilainya yaitu sebesar 63,94. Koefisien regresi variabel minat belajar siswa sebesar -0,46: artinya jika intensitas penggunaan game gadget mengalami kenaikan 1, maka minat belajar siswa (Y) akan mengalami penurunan sebesar 0,46. Koefisien bersifat negatif artinya terjadi hubungan negatif antara variabel intensitas penggunaan game gadget $(\mathrm{X})$ dan variabel minat belajar siswa $(\mathrm{Y})$, semakin naik intensitas penggunaan game gadget maka semakin menurun minat belajar siswa.

Berdasarkan penelitian terdahulu, perbandingan penelitian ini dengan penelitian Angela, yaitu pengaruh game online terhadap motivasi belajar siswa SDN 015 Kelurahan Sidomulyo Kecamatan Samarinda Ilir tahun pelajaran 2012/2013. Penelitian Angela, mengungkap pengaruh game online online terhadap motivasi belajar adalah sebesar $29 \%$. Hal ini terbukti signifikan dengan $\mathrm{t}$ hitung $(8,753)>\mathrm{t}$ tabel $(1,665)$ yang berarti hipotesis $\mathrm{Ha}$ diterima. Game online mempengaruhi perubahan motivasi belajar di dalam diri pelajar-pelajar sekolah karena semakin sering bermain game online motivasi belajar akan ikut menurun dengan sendirinya, karena ini disebabkan kelelahan yang terjadi setelah bermain sehingga ketika di rumah lebih memilih beristirahat daripada belajar sehingga waktu untuk belajar bahkan mengulang kembali pelajaran tidak ada waktu, dengan ini tidak jarang anak tidak konsentrasi bahkan sibuk sendiri ketika mengikuti pembelajaran di kelas. ${ }^{37}$

Jadi, kaitan penelitian ini dengan penelitian Angela dan Harahap adalah memiliki persamaan hasil penelitian, yaitu game merupakan salah satu faktor yang mempengaruhi motivasi, prestasi dan minat belajar siswa. Dari hasil penelitian ini, game gadget memberikan

${ }^{36}$ Elizabeth Hurlock, Perkembangan Anak..., hlm. 147.

${ }^{37}$ Angela, Pengaruh Game Online Terbadap Motivasi Belajar Siswa", Ilmu Komunikasi, Vol. 1, Nomor 2, 2013, hlm. 541-542. 
sumbangan pengaruh sebesar 40\% terhadap minat belajar siswa, yang membuat anak melamun, tidak fokus belajar, tidak konsentrasi, tidak memperhatikan pembelajaran waktu di sekolah, dan membuat anak ingin cepet pulang pada saat anak berada di sekolah. Ketika di rumah anak memilih untuk bermain game gadget, sehingga mengurangi waktu belajar anak.

Kecanduan dalam bermain game gadget dapat membahayakan bagi anak, diantaranya: bahaya radiasi dari gadget, berpengaruh pada kinerja otak anak, minat dan prestasi belajar menurun. Setiap gadget atau prangkat elektronik memancarkan radiasi. Paparan radiasi dari prangkat elektronik ini dapat berakibat pada kelemahan kinerja otak anak. Masalah kinerja otak yang sering dijumpai pada anak pecandu game adalah masalah konsentrasi. Anak akan selalu merasa senang ketika bermain game, dan hal ini berakibat adanya perubahan struktur dendrit sel-sel di otak. Permasalahan sel ini pada akhirnya berpengaruh pada kemampuan anak dalam mengontrol perilaku dan kemampuan konsentrasinya dalam jangka panjang. Saat konsentrasi anak menurun, maka ia juga akan mudah lupa dan gagal fokus. Jika gangguan ini berlangsung selama proses pembelajaran di sekolah. Anak akan kesulitan memahami dan mengikuti pembelajaran yang diberikan oleh guru. Pada akhirnya minat belajar dan prestasi belajar anak akan menurun. 38

Sedangkan menurut Priska, anak yang kecanduan bermain game gadget dapat mengancam dirinya dan lingkungannya, tidak mau sekolah, ketika di rumah mengalami perubahan prilaku, lebih banyak berbohong kepada orang tuanya, lebih banyak mengurung diri di dalam kamar, dan lebih sensitif kepada orangtuanya, menunjukan emosi yang tidak normal kepada orang tuanya. ${ }^{39}$ Dengan kecanggihan alat teknologi seperti gadget ini, kita tidak bisa menghambat alat-alat ini muncul. Maka dari itu perlu pendampingan serta pengawasan yang lebih terhadap anak dalam menggunakan gadget-nya dan memberikan waktu penggunaannya agar anak tidak kecanduan bermain game gadget, dan orangtua juga jangan kalah canggih dengan anak dalam menggunakan teknologi agar tidak dikerjai dan dibohongi oleh anak

38Siti Rokhani,"Dampak Bermain Game Gadget Terhadap Anak", dalam http// dokteranak.org/dampak-negatif-bermain-game-untuk-anak, diakses tanggal 6 Juni 2018, pukul 20.15

${ }^{39}$ Dewi Priska , "W aspada Kecanduan Gawai” Berita iNEWS di Kalangan Masyarakat Bondowoso Jawa Timur" Di Tayangkan Tanggal 19 Januari 2018, Pukul 13:00. 
Dengan demikian dapat ditarik sebuah kesimpulan bahwa intensitas penggunaan game gadget merupakan salah satu faktor yang cukup kuat mempengaruhi minat belajar siswa. Dimana dengan rutinitas/keseringan penggunaan game gadget pada anak dapat menyebabkan minat belajar anak waktu di sekolah dan di rumah menjadi menurun, dan dampak penggunaan game gadget yang cukup lama juga dapat membahayakan kesehatan serta sosial anak. Hal ini disebabkan karena kurangnya pengawasan orang tua terhadap anak-anaknya pada saat bermain game gadget dan tidak membatasi waktu bermain anak-anaknya. Dari hasil penelitian ini, intensitas penggunaan game gadget dapat memberikan sumbangan pengaruh sebesar 40\% (cukup kuat) untuk mempengaruhi minat belajar siswa kelas V MI NW Gelogor tahun pelajaran 2017/2018.

\section{SIMPULAN DAN SARAN}

\section{Simpulan}

Berdasarkan hasil penelitian dan pembahasan, dapat disimpulkan bahwa terdapat pengaruh yang signifikan antara intensitas penggunaan game gadget terhadap minat belajar siswa kelas V MI NW Gelogor tahun pelajaran 2017/2018. Hal ini dibuktikan dengan hasil uji t yang diperoleh yaitu t hitung -3,982 dan t tabel 2,064. Dengan hasil korelasi -0,63081, hal ini menunjukan bahwa pengaruh intensitas penggunaan game gadget terhadap minat belajar siswa berkorelasi negatif kuat. Dengan persamaan regresi $Y=63,94-0,46 \mathrm{X}$. Konstanta sebesar 63,94 artinya jika intensitas penggunaan game gadget $(\mathrm{X})$ nilainya 0 , maka minat belajar siswa (Y) nilainya yaitu sebesar 63,94. Koefisien regresi variabel minat belajar siswa sebesar -0,46 artinya jika intensitas penggunaan game gadget mengalami kenaikan 1, maka minat belajar siswa (Y) akan mengalami penurunan sebesar -0,46. Intensitas penggunaan game gadget pada penelitian ini memberikan sumbangan terhadap minat belajar sebesar 40\% yang cukup kuat untuk mempengaruhi minat belajar siswa.

\section{Saran}

Berdasarkan hasil penelitian ini, disarankan kepada orang tua untuk membatasi anaknya dalam menggunakan game gadget dan mendamping/mengawasi mereka pada saat bermain game gadget. Bagi guru dan sekolah diharapkan terus melakukan sosialiasi kepada siswanya mengenai bahaya game gadget jika digunakan atau dimaininkan secara berlebihan. Hendaknya guru dan sekolah meminta siswanya untukl ebih menekuni/mengerjakan aktifita-aktifitas yang lebih positif. 


\section{DAFTAR PUSTAKA}

Angela, 2013. ejournal Ilmu Komunikasi, "Pengaruh Game Online Terhadap Motivasi Belajar Siswa”Vol. 1, Nomor 2, hlm. 532

Astuti, Alfira Mulya. 2015. Statistik Penelitian. Mataram: Ihsan Madani

Dahar, Ratna Wilis. 2011. Teori-Teori Belajar Dan Pembelajaran. Jakarta: Erlangga.

Dalyono, M. 2012. Psikologi Pendidikan. Jakarta: Rineka Cipta.

Djaali. 2011. Psikologi Pendidikan. Jakarta: Bumi Aksara.

Djamarah, Syaiful Bahri. 2015. Psikologi Belajar. Jakarta: Rineka Cipta.

Priska, Dewi. "Waspada Kecanduan Gawai" Berita iNEWS di Kalangan Masyarakat Bondowoso Jawa Timur” Di Tayangkan pada Tanggal 19 Januari 2018, Pukul 13:00.

Furqon, 2013. Statistik Terapan Untuk Penelitian Bandung: Alfabeta.

Harahap, Khairani 2013. studi korelasional, “pengarub Game Online Terbadap Prestasi Belajar Siswa Kelas VIII SMP Nurul Hasanah Kelurahan Padang Bulan Meda”, vol. 1.

Hurlock, Elizabet. 2010. Perkembangan Anak. Jilid 2 (Terjemahan Meitasari Tjandrosa). Jakarta: Erlangga.

Khairani, Makmum. 2014. Psikologi Belajar. Yogyakarta: Aswaja Pressindo.

Echols, John M. \& Hassan Shadily. 1996. Kamus Inggris Indonesia, Jakarta: Gramedia Pustaka Utama,

Miarso, Yusufhadi. 2004. Menyamai Benih Teknologi Pendidikan. Jakarta: Kecana.

Nasional, Depertemen Pendidikan. 2008. Kamus Besar Bahasa Indonesia. Jakarta: Balai Pustaka.

Nasution. 2010. Dikdaktik Asas-asas Mengajar. Jakarta: Bumi Aksara.

Nazir, Moh. 2014. Metode Penelitian. Bogor: Ghalia Indonesia.

Novitasari, Wahyu. jurnal paud teratai "Dampak Penggunaan Gadget Terhadap Interksi Sosial Anak Usia 5-6 Tahun”, Vol. 05, Nomor 03, Tahun 2016, 
Observasi, Hasil di MI NW Gelogor, 2017. pada tanggal 16 november.

Rokhani, Sit. i'Dampak Bermain Game Gadget Terhadap Anak", dalam http//dokteranak.org/dampak-negatif-bermain-game-untuk-anak, diakses tanggal 6 Juni 2018.

Saefullah, 2012. Psikologi Perkembangan Dan Pendidikan. Bandung: Pustaka Setia.

Sardiman, 2016. Interaksi Dan Motivasi Belajar Mengajar. Jakarta: Rajawali Pers.

Scribd, "Pengertian intensitas". dalam https://www.scribd.com/doc/316536693/ Pengertian-Intensitas, diakses tanggal 6 juni 2018.

Simbolon, Naeklan. "Faktor-Faktor yang Mempengaruhi Minat Belajar Peserta Didik", dalam http//jurnal.unimed.ac.id/2012/index.php/elementary/article/view/1323, diakses tanggal 6 juni 2018.

Sopiah, Etta Mamang Sangadji \&. 2010. Metodelogi Penelitian Pendekatan Praktis Dalam Penelitian, Yogyakarta: Andy.

Subana, Dkk, 2000. Statistik Pendidikan. bandung: pustaka setya.

Sugiyono, 2016. Metode Penelitian kuantitatif, Kualitatif, Dan R\&D, Bandung: Alfabeta.

Sugiyono, 2017. Metode Penelitian kuantitatif, Kualitatif, Dan R\&D, Bandung: Alfabeta.

Umar, Husein. 2014. Metode Penelitian Untuk Skripsi Dan Tesis Bisnis, Jakarta: Rajawali Pers.

Usman, Moch. Uzer. 2011. Menjadi Guru Professional. Bandung: Remaja Rosdakarya

Wawancara, Hasil Beberapa Siswa MI NW Gelogor, 2017. Pada Tanggal 16 November.

Wikipedia, (Last Modified 2013). 2017. "Video Game", dalam http://en.wikipedia.org/wiki/Video game, diakses 28 november,

Yaumi, Muhammmad. 2014. Pendidikan Karakter Landasan, Pilar, Dan Implementasi, Jakarta: Kencana.

Zanikhan, 2017. "Pengertian Minat Belajar", dalam http://zanikhan.multiply.com/journal/item di akses tanggal 3 Desember, pukul 09.24 . 